\title{
PENGEMBANGAN BUKU PENGAYAAN PENGETAHUAN TENTANG LASER UNTUK SISWA SMA
}

\author{
Diah Kusumawardhani $^{1, \mathrm{a})}$, Siswoyo ${ }^{1, \mathrm{~b})}$, Riser Fahdiran ${ }^{2, \mathrm{c})}$ \\ ${ }^{1}$ Prodi Pendidikan Fisika, FMIPA, Universitas Negeri Jakarta, \\ ${ }^{2}$ Prodi Fisika, FMIPA, Universitas Negeri Jakarta, \\ Jl. Rawamangun Muka, Jakarta Timur, Indonesia, 13220
}

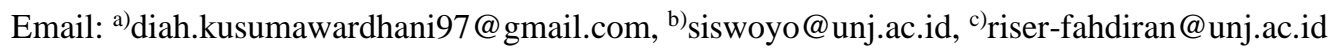

\begin{abstract}
Abstrak
Tujuan dari penelitian ini adalah mengembangkan buku pengayaan pengetahuan tentang laser yang layak digunakan sebagai bahan ajar pada program pengayaan. Metode yang digunakan adalah Research and Development $(R \& D)$ yang mengacu pada model Dick \& Carey. Langkah-langkah model pengembangan Dick \& Carey yang dilakukan pada penelitian ini mencakup sembilan tahap yang dimulai dari mengidentifikasi tujuan pembelajaran umum, sampai melakukan revisi terhadap bahan pembelajaran. Buku yang dikembangkan mengikuti pedoman dari Pusat Kurikulum dan Perbukuan (Puskurbuk) sebagai bahan ajar untuk siswa SMA. Buku dikembangkan dengan menggunakan bahasa yang komunikatif, juga dilengkapi dengan ilustrasi-ilustrasi yang menarik, serta informasi tentang laser yang mengikuti perkembangan IPTEK terkini. Pengembangan buku pengayaan pengetahuan ini memiliki tingkat kesesuaian untuk dijadikan sebagai referensi bahan ajar pada program pengayaan.
\end{abstract}

Kata-kata kunci: Penelitian dan Pengembangan, Buku Pengayaan Pengetahuan, Laser

\begin{abstract}
The purpose of this research is developing a knowledge-enrichment physics book about lasers that is worthy of being used as teaching materials in enrichment programs. The method is Research and Development (R\&D) which refers to the Dick \& Carey model. The steps of the Dick \& Carey development model carried out in this study includes nine stages, from identifying general learning goals until revising learning materials. The book developed follows the guidelines of the Center for Curriculum and Books (Puskurbuk) as a teaching material for high school students. The book was developed using communicative language, also equipped with interesting illustrations, as well as information about lasers that followed the latest developments in science and technology. The development of this knowledge-enrichment book has a level of conformity that is sufficient to be used as a reference for teaching materials in enrichment programs.
\end{abstract}

Keywords: R\&D, Knowledge-Enrichment Book, Laser 


\section{PENDAHULUAN}

Kegiatan belajar mengajar akan berlangsung jika dilengkapi dengan komponen-komponen pembelajaran. Salah satu komponen pembelajaran ialah media pembelajaran. Namun, media pembelajaran yang saat ini sudah ada di sekolah umumnya belum dimanfaatkan secara maksimal [1]. Padahal penggunaan media pembelajaran sangat diperlukan untuk mengefektifkan interaksi antara guru dan siswa [2]. Oleh karena itu, perlu dilakukan pengembangan media pembelajaran, agar dapat digunakan semaksimal mungkin dalam kegiatan pembelajaran. Salah satu media pembelajaran yang sampai saat ini masih digunakan dalam kegiatan belajar mengajar adalah buku [3]. Penggunaan buku di sekolah pun tidak maksimal, kebanyakan perpustakaan di sekolah hanya menyediakan buku-buku paket atau buku-buku teks yang isinya terlalu tekstual dan kurang mengaitkan materi yang dipelajari dengan kehidupan sehari-hari sehingga menyebabkan siswa kesulitan dalam belajar [4].

Berdasarkan penelitian Tosun yang berjudul A Study on Reading Printed Books or E-Books: Reasons for Student-Teachers Preferences (2014), bahwa sebanyak 204 dari 258 responden lebih memilih untuk membaca buku cetak daripada buku elektronik atau e-book dengan alasan buku cetak lebih mudah dibaca dan lebih efektif, serta dapat melindungi kesehatan mata [5]. Selain itu, buku cetak masih menjadi media pembelajaran yang paling sesuai dengan kebutuhan optik, kognitif, dan metakognitif dari otak ketika membaca [6]. Hal ini yang menyebabkan mengapa buku cetak masih banyak digunakan dan digemari oleh pembaca walaupun sudah banyak buku elektronik yang beredar.

Buku yang digunakan oleh Satuan Pendidikan terbagi menjadi dua yaitu buku teks pelajaran dan buku nonteks pelajaran [7]. Adapun yang termasuk ke dalam buku nonteks pelajaran antara lain: buku pengayaan, buku referensi, dan buku panduan pendidik [8]. Buku pengayaan adalah buku yang memuat materi yang dapat memperkaya buku teks pelajaran. Buku jenis ini tidak hanya ditujukan untuk peserta didik, melainkan dapat digunakan juga oleh pihak lain atau masyarakat pada umumnya [9]. Buku pengayaan bisa dijadikan sebagai pendukung proses pembelajaran di luar penggunaan buku teks, yakni untuk menambah pengetahuan dan kecakapan peserta didik.

Salah satu kompetensi dasar yang harus dicapai oleh peserta didik melalui pembelajaran di sekolah adalah gelombang. Materi gelombang merupakan salah satu materi tersulit bagi siswa, padahal aplikasi dari materi gelombang sudah banyak digunakan di kehidupan sehari-hari yaitu gelombang elektromagnetik. Siswa merasa kesulitan dalam memahami materi gelombang elektromagnetik sehingga perlu dilakukan pengembangan bahan ajar (buku) yang berkaitan dengan gelombang elektromagnetik [10].

Salah satu aplikasi gelombang elektromagnetik dalam kehidupan sehari-hari adalah laser. Dalam beberapa buku teks pelajaran fisika yang digunakan di sekolah-sekolah di Indonesia, (salah satunya buku karangan Marthen Kanginan), materi laser tidak dibahas secara rinci dan detail, yakni hanya sebagai tambahan pengetahuan saja pada materi gelombang cahaya atau gelombang elektromagnetik. Selain itu, menurut data dari Kepala Pusat Kurikulum dan Perbukuan (Puskurbuk) tentang daftar judul buku pengayaan pengetahuan yang memenuhi syarat kelayakan untuk digunakan sebagai sumber belajar tahun 2014-2016, belum terdapat buku pengayaan pengetahuan untuk siswa SMA yang membahas tentang laser [11]. Sehingga perlu dikembangkan buku pengayaan pengetahuan tentang laser yang layak digunakan sebagai bahan ajar pada program pengayaan untuk siswa SMA.

\section{METODE PENELITIAN}

Metode penelitian yang digunakan adalah metode penelitian dan pengembangan (research \& development), yaitu metode yang menghasilkan suatu produk dan menguji keefektifan produk tersebut [12]. Model yang digunakan adalah dick \& carey. Langkah-langkah penelitian pengembangan dick and carey dalam The systematic design of instruction [13] adalah sebagai berikut: (1) Mengidentifikasi tujuan pembelajaran, (2) Melakukan analisis pembelajaran, (3) Menganalisis karakteristik peserta didik dan konteks pembelajaran, (4) Merumuskan tujuan pembelajaran khusus, (5) Mengembangkan instrumen penilaian, (6) Mengembangkan strategi pembelajaran, (7) Mengembangkan dan memilih bahan ajar, (8) Merancang dan mengembangkan evaluasi formatif, (9) Melakukan revisi bahan pembelajaran, dan (10) Merancang evaluasi sumatif. 
Buku pengayaan pengetahuan yang dikembangkan mengacu pada kriteria penilaian buku pengayaan pengetahuan oleh Pusat Kurikulum dan Perbukuan (Puskurbuk). Dalam proses desainnya, buku pengayaan yang dikembangkan juga mengomparasi dengan buku pengayaan yang telah ada [14-15]. Instrumen untuk validasi yang digunakan untuk menguji kelayakan buku berupa uesioner skala likert dengan responden ahli materi, media, dan pembelajaran.

\section{HASIL DAN PEMBAHASAN}

Hasil dari penelitian ini berupa buku pengayaan pengetahuan tentang laser yang menyajikan 4 bab, yaitu sejarah laser, cara kerja laser, jenis-jenis laser, dan manfaat laser dalam kehidupan seharihari. Beberapa tampilan dari buku yang dihasilkan adalah sebagai berikut:

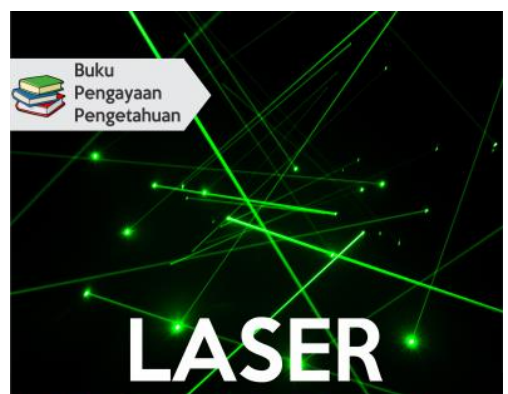

Light Amplification by Stimulated Emission of Radiation

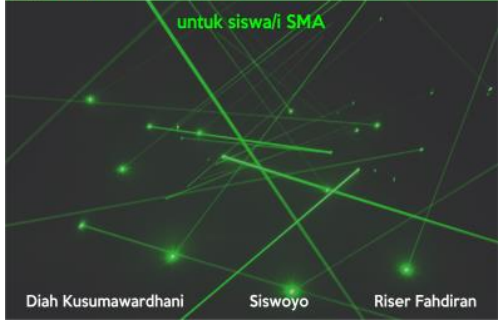

(a)

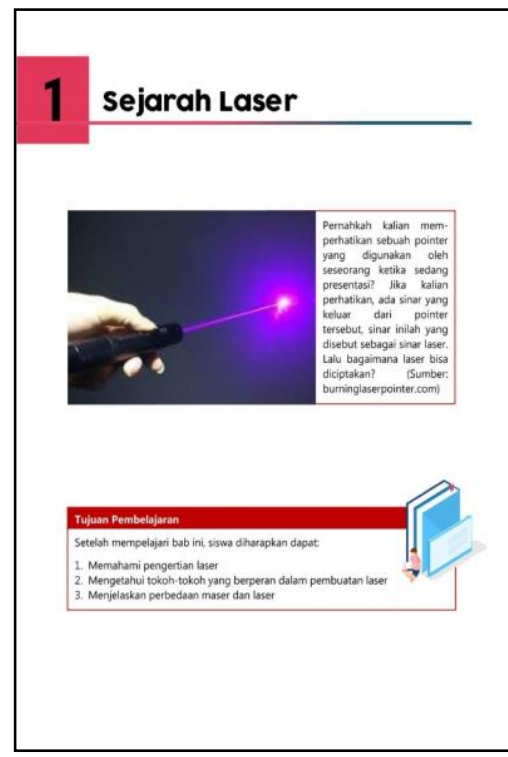

(b)

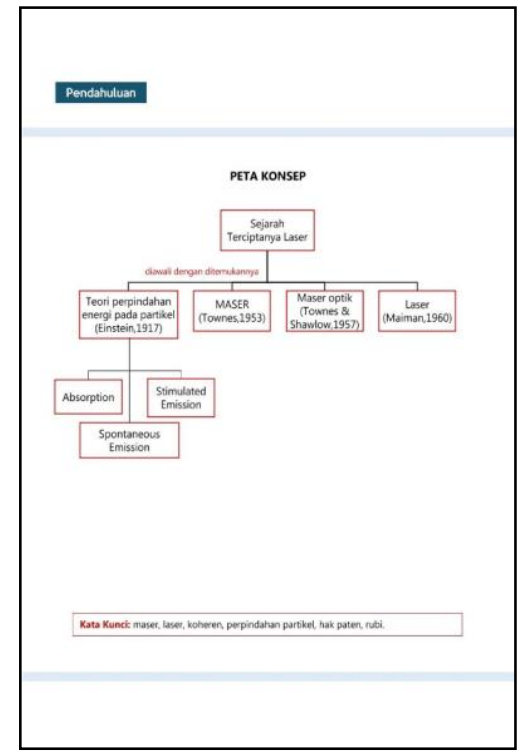

(c)

GAMBAR 1. (a) Tampilan sampul depan (cover) buku, (b) tampilan sampul bab buku, (c) tampilan peta konsep, tujuan dan kata kunci pada setiap bab

Buku pengayaan yang dikembangkan memiliki beberapa komponen yang membedakannya dengan buku pengayaan lain. Komponen-komponen tersebut ada di setiap bab dan diawali dengan "Pendahuluan" yang berisi pendahuluan sebelum memasuki bab, kemudian "Materi" yang merupakan bagian inti buku, "Ayo Bertanya" berisi pertanyaan untuk menggali informasi \& mengarahkan siswa pada hal yang belum diketahui, "Ayo Berdiskusi" berisi pertanyaan yang dapat didiskusikan dengan orang lain, "Let's Try" Bagian ini berisi hal-hal yang dapat dilakukan siswa seperti mencoba simulasi laser atau melakukan praktikum sederhana, "Kesimpulan" berisi poin-poin penting yang telah dipelajari selama satu bab, dan "Let's Play" berisi permainan (berupa TTS) yang dapat dikerjakan oleh siswa setelah membaca materi buku. 


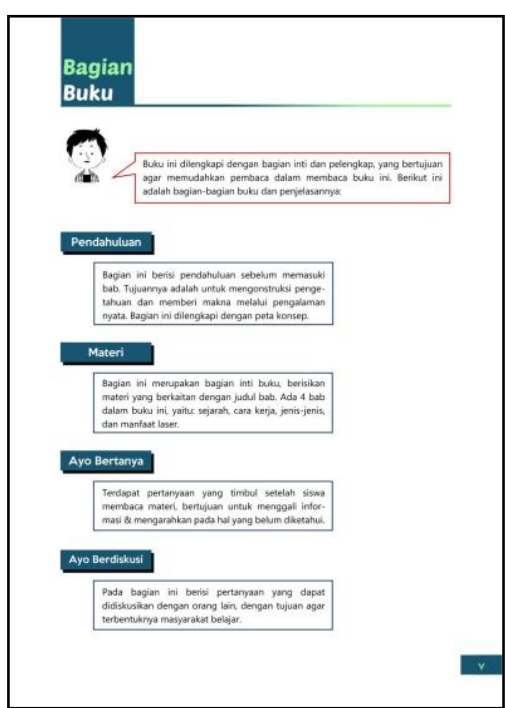

(a)

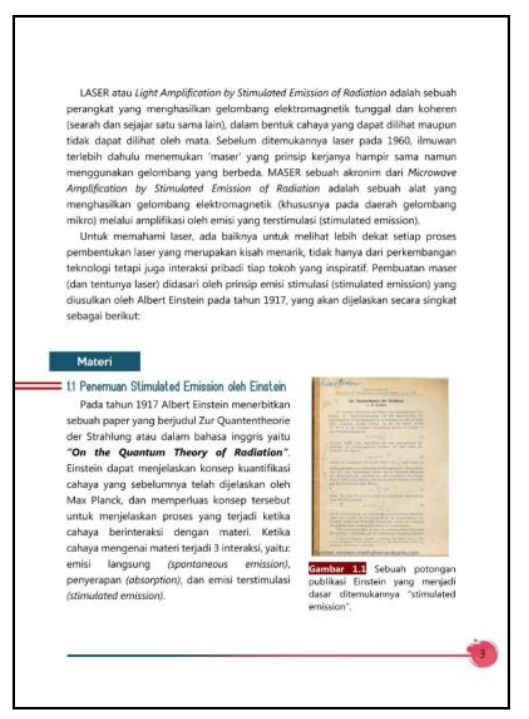

(b)

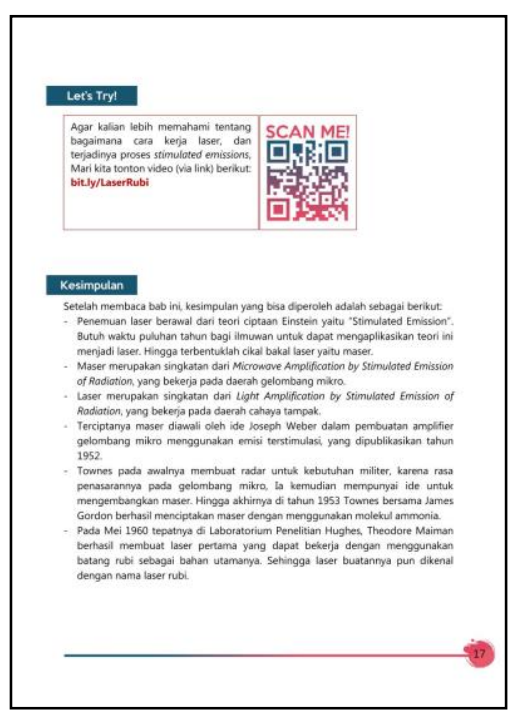

(c)

GAMBAR 2. (a) Komponen-komponen dalam buku pengayaan yang dijelaskan sebelum memasuki bab,

(b) tampilan komponen materi, (c) tampilan komponen let's try dan kesimpulan

Selain komponen yang telah disebutkan, terdapat pula komponen seperti "seputar laser" yang berisikan info-info tentang laser, dan "tahukah kamu" yang berisi tentang informasi-informasi terbaru yang berkaitan dengan laser. Buku ini dilengkapi gambar di setiap halamannya yang dapat membuat pembaca merasa lebih tertarik untuk belajar dan memahami materi yang berkaitan. Bahasa yang digunakan dalam buku ini menggunakan bahasa yang komunikatif dan ringan sehingga mudah dipahami oleh pembaca. Pada setiap bab dalam buku ini dilengkapi dengan langkah-langkah pembelajaran kontekstual, yang diawali dengan pendahuluan, materi, ayo bertanya, mari diskusi, contoh, dan kesi

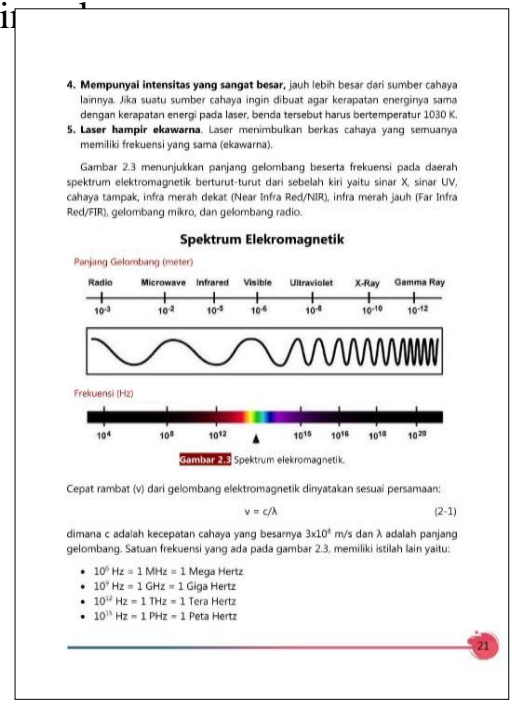

(a)

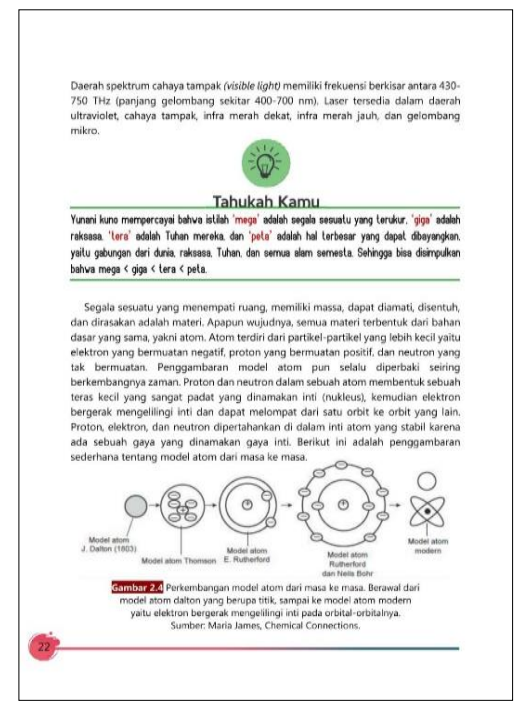

(b)

GAMBAR 3. (a) Materi dalam buku dilengkapi dengan gambar dan keterangannya, (b) tampilan komponen tahukah kamu yang berfungsi untuk memperjelas isi buku 
Buku pengayaan pengetahuan ini divalidasi kepada tiga orang ahli yaitu ahli materi, ahli media, dan ahli pembelajaran. Penilaian dan saran dari para ahli lalu dijadikan sebagai bahan pertimbangan untuk merevisi dan memperbaiki buku pengayaan yang sudah dibuat sehingga produk yang dihasilkan memiliki kualitas yang lebih baik lagi. Setelah dilakukan uji kelayakan terhadap ahli materi dan ahli pembelajaran, diperoleh hasil sebagai berikut:

TABEL 1. Hasil uji kelayakan

\begin{tabular}{ccc}
\hline No. & Ahli & Rata-rata Skor \\
\hline 1 & Materi & $72,9 \%$ \\
2 & Media & $91,67 \%$ \\
3 & Pembelajaran & $85,83 \%$ \\
\hline
\end{tabular}

Dari data pada tabel tersebut, bila hasil dari ketiga ahli ini dirata-ratakan maka akan memperoleh persentase sebesar 83,2\% dengan interpretasi "sangat layak". Berdasarkan hal tersebut, buku pengayaan pengetahuan tentang laser yang dikembangkan dinyatakan layak untuk digunakan dalam kegiatan pembelajaran.

\section{SIMPULAN}

Berdasarkan hasil penelitian, dapat disimpulkan bahwa buku pengayaan pengetahuan tentang laser yang dikembangkan memperoleh persentase sebesar 72,9\% pada aspek materi, $91,67 \%$ pada aspek media, dan $85,83 \%$ pada aspek pembelajaran. Jika diinterpretasikan berdasarkan skala kelayakan, buku pengayaan pengetahuan tentang laser ini layak digunakan sebagai bahan ajar pada program pengayaan di SMA.

\section{UCAPAN TERIMA KASIH}

Terimakasih saya ucapkan kepada Allah SWT. Terimakasih kepada dosen pembimbing, keluarga, serta teman-teman yang telah memberikan bantuan baik secara materi maupun dukungannya demi terselesainya penelitian ini.

\section{REFERENSI}

[1] A. Prastowo, Sumber Belajar dan Pusat Sumber Belajar, Depok: Prenadamedia Group, 2018.

[2] A. Rofiah, C. E. Rustana, dan H. Nasbey, "Pengembangan Buku Pengayaan Pengetahuan Berbasis Kontekstual pada Materi Optik," Jurnal Penelitian \& Pengembangan Pendidkan Fisika, vol. 4, 2015, pp. 1-4,.

[3] F. Bakri, R. Rasyid, and R. D. A. Mulyaningsih, "Pengembangan Modul Fisika Berbasis Visual untuk Sekolah Menengah Atas (SMA)," Jurnal Penelitian dan Pengembangan Pendidikan Fisika, Vol. 1, No. 2, 2015, pp. 67-74

[4] R. Hartagung, Sunaryo, dan R. Fahdiran, "Pengembangan Buku Pengayaan Dari Evolusi Bintang Hingga Gelombang Gravitasi untuk Siswa SMA," PROSIDING SNF, vol. 7, 2018, pp. 78-83,

[5] N. Tosun, "A Study on Reading Printed Books or E-books: Reasons for Student-Teacher Preferences," OJET: The Turkish Online Journal of Educational Technology, vol. 13, 2014, pp. 21-28.

[6] M. Tanner, "Digital vs Print: Reading Comprehension and the Future of the Book," SLIS Student Research Journal, vol. 4, 2014. 
[7] Pusat Kurikulum dan Perbukuan, Pedoman Penulisan Buku Nonteks, Jakarta: Pusat Perbukuan Depdiknas, 2014.

[8] Kemendikbud, Peraturan Menteri Pendidikan dan Kebudayaan Nomor 8 Tahun 2016 Tentang Buku oleh Satuan Pendidikan, Jakarta: Kemendikbud, 2016.

[9] Kemendikbud, Peraturan Menteri Pendidikan Nasional Nomor 2 Tahun 2008 Tentang Buku, Jakarta: Depdiknas, 2008.

[10] N. Nurjannati, M. Irianti dan M. Rahmad, "Pengembangan E-Modul Berbasis Literasi Sains pada Materi Radiasi Elektromagnetik," Jurnal Online Mahasiswa (JOM) FKIP Universitas Riau, 2017, pp. 2-11,.

[11] Kemendikbud Baitbang Puskurbuk, Penetapan Buku Pengayaan Sebagai Buku Nonteks Pelajaran yang Memenuhi Syarat Kelayakan untuk digunakan sebagai Sumber Belajar Pada Jenjang Pendidikan Dasar dan Menengah, Jakarta: Kemendikbud, 2014-2016.

[12] Sugiyono, Metode Penelitian Kuantitatif, Kualitatif, dan R\&D, Bandung: Alfabeta, 2017.

[13] W. Dick and L. Carey, The Systematic Design of Instruction, USA: Harper Collins Publishers, 2015.

[14] Desnita, N. Fadilah, and E. Budi, "Pengembangan Buku Pengayaan Kajian Fisis Peristiwa Angin Puting Beliung untuk Siswa SMA," Jurnal Penelitian dan Pengembangan Pendidikan Fisika, Vol. 2, No. 2, 2016, pp. 97-104.

[15] S. Maulana, D. Desnita, and R. Raihanati, "The Development of Knowledge Enrichment Books Concerning Ice and Snow Physical Studies for High-School Students", Jurnal Penelitian dan Pengembangan Pendidikan Fisika, 2018, vol. 4, no. 2, pp. 83 - 90. 